\title{
IMPLEMETASI OFFLINE PENGENALAN SISTEM ISYARAT BAHASA INDONESIA MENGGUNAKAN METODE DYNAMIC TIME WARPING PADA PERANGKAT ANDROID
}

\author{
Mohammad Iqbal \\ Program Studi Teknik Elektro \\ Fakultas Teknik, Universitas Muria Kudus \\ Email: iqbal.umk@gmail.com \\ Endang Supriyati \\ Program Studi Teknik Informatika \\ Fakultas Teknik, Universitas Muria Kudus \\ Email: esupriyati@gmail.com \\ Tri Listyorini \\ Program Studi Teknik Informatika \\ Fakultas Teknik, Universitas Muria Kudus \\ Email: trilistyorini.ti.umk@gmail.com
}

\begin{abstract}
ABSTRAK
Algoritma Dynamic Time Warping (DTW) digunakan secara luas untuk berbagai penelitian, salah satunya di bidang bahasa isyarat. DTW adalah algoritma pencocokan pola (template matching) untuk mengukur kemiripan dua data sekuensial (time series) temporal yang berbeda waktu dan kecepatan. Pada penelitian ini disajikan implementasi algoritma DTW untuk pengenalan bahasa isyarat Indonesia (Sistem Isyarat Bahasa Indonesia SIBI) secara offline. Dataset yang digunakan dalam penelitian ini sebanyak 900 data untuk dengan jumlah kelas 50 kata isyarat, yaitu dengan rincian untuk masing-masing kelas adalah 3 data sebagai data template dan 15 data sebagai data testing. Hasil pengujian menunjukkan bahwa tingkat pengenalan atau nilai accuracy adalah $89,73 \%$. Waktu rata-rata yang dibutuhkan adalah 654.59 milidetik untuk proses pengenalan satu data testing dengan menggunakan template sebanyak 3 data per kelas atau total template 150 data.
\end{abstract}

Kata kunci: pengenalan, offline, SIBI, bahasa isyarat Indonesia, android.

\section{ABSTRACT}

Algorithm Dynamic Time Warping (DTW) is used widely to various studies, one in the field of sign language. DTW is template matching algorithm to measure the similarity of the two data sequential (time series) with different time and speed. In this study are presented DTW algorithm implementation for the offline recognition of Indonesia sign language (Sistem Isyarat Bahasa Indonesia - SIBI). The dataset used in this study were 900 data for the number of grade 50 cue words, with details for each class is 3 the data as a data template and 15 of data as a data testing. The results show that the recognition rate or accuracy value is $89.73 \%$. The average time needed is 654.59 milliseconds for the introduction of the testing of data using a data template as much as 3 per class or template total of 150 data.

Keywords: recognition, offline, SIBI, Indonesia sign language, android

\section{PENDAHULUAN}

Telah banyak penelitian dengan menggunakan algoritma DTW (Dynamic Time Warping) yaitu pengenalan gesture [1], dengar cara menghitung jarak terdekat antara dua vektor ciri menggunakan DTW untuk memperbaiki akurasi pengenalan. Dengan pendekatan baru ini mampu menunjukkan kemampuan yang signifikan dalam mengenali multiple gesture, mengidenfifikasikan awal dan akhir pada sekuen waktu. Performa kinerja lebih baik dibanding dengan DTW klasik. Pengenalan emosi manusia [2] seperti marah, senang, sedih dapat dikenali melalui gesture tubuh manusia. Metode ini digunakan untuk analisis perilaku emosional berdasarkan klasifikasi dari time series dan pada model yang menyediakan indikator yang menggambarkan dinamika gerak isyarat ekspresif. Pengenalan aktifitas manusia [3] penelitian ini fokus untuk mengenali beberapa tindakan manusia seperti melambaikan tangan, meninju, bertepuk tangan, dll. Untuk meningkatkan tingkat pengenalan, dilakukan pelacakan tubuh menggunakan kamera mendalam untuk memulihkan informasi bagian sendi tubuh manusia di dunia real 3D sistem koordinat. Kemudiani membangun vektor fitur dari orientasi bersama time series yang invarian dengan ukuran tubuh manusia. DTW kemudian diterapkan pada vektor fitur dihasilkan. Model transisi perpindahan[4] algoritma clustering DTW sebagai ukuran jarak diusulkan untuk gerakan pengelompokan transisi antara dua 
isyarat, dan kemudian algoritma yang sesuai disajikan untuk pelatihan model-model gerakan transisi. Algoritma pelatihan dapat membagi secara otomatis transisi gerakan dengan iterasi bootstrap, di mana algoritma temporal digunakan untuk cluster gerakan transisi. Percobaan menunjukkan bahwa pengenalan bahasa isyarat berkesinambungan berdasarkan model gerakan transisi memiliki kinerja yang baik selama kosakata besar .

Pada penelitian ini disajikan implementasi algoritma DTW untuk pengenalan bahasa isyarat Indonesia secara offline. Dataset yang digunakan dalam penelitian ini sebanyak 900 data untuk dengan jumlah kelas 50 kata isyarat, yaitu dengan rincian untuk masing-masing kelas adalah 3 data sebagai data template dan 15 data sebagai data testing.

Pada dasarnya algoritma DTW adalah algoritma pemprograman dinamis, dengan menggunakan update rekursif dengan cara menjumlahkan jarak elemen yang dipetakan dari setiap langkah rekursif. Perhitungan jarak antar dua elemen sering menggunakan algoritma jarak Euclidean, untuk mencari derajat kemiripan (similiarity) antara dua data sekuensial (time series), untuk panjang data yang sama. Tetapi untuk dua data sekuensial dengan panjang data yang yang berbeda, maka digunakan algoritma DTW.

\section{METODOLOGI PENELITIAN}

Blok desain sistem pengenalan offline bahasa isyarat Indonesia adalah seperti pada gambar 1 . Implementasi secara offline pada perangkat android, dilakukan mulai dari pengolahan data file untuk mendapatkan ciri (proses ektraksi ciri), proses pencocokan pola sampai dengan mendapatkan hasil yang cocok dari data template.

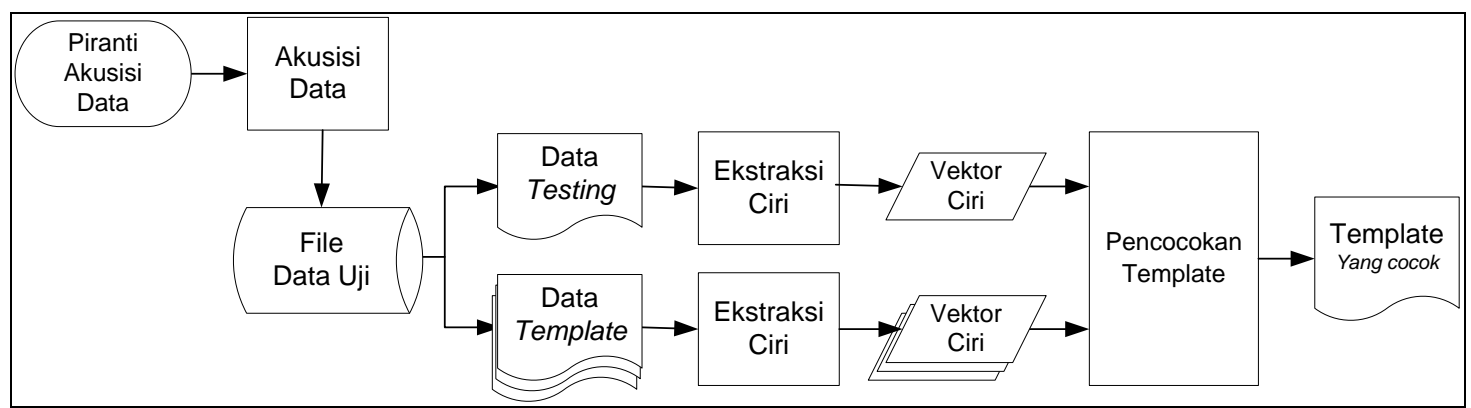

Gambar 1. Diagram Blok Desain Sistem Pengenalan Offline Bahasa Isyarat Indonesia [7]

Hasil akusisi data disimpan ke dalam bentuk file dan dijadikan sebagai data uji. Data uji tersebut dibagi menjadi dua sebagai data testing dan data template, untuk kemudian dilakukan ekstraksi ciri untuk mendapatkan vektor ciri dan dilanjutkan dengan pencocokan template untuk mencari data template yang cocok dengan data testing, berdasarkan jarak terdekat menggunakan metode DTW.

\subsection{Data Uji}

Data uji yang digunakan pada penelitian ini adalah data uji yang didapatkan dengan menggunakan piranti akuisi data yang digunakan pada penelitian[5][7]. Gerakan isyarat untuk SIBI yang digunakan pada penelitian ini adalah mengacu pada kamus isyarat bahasa Indonesia dan portal i-chat (http://ichat.org). Kata isyarat yang dipilih adalah kata isyarat yang dengan satu tangan, yaitu tangan kanan. Data penelitian berupa data kata isyarat yang terdiri dari 50 kelas atau jenis kata isyarat. Total data uji yang digunakan sebagai data template adalah 3 data per kelas atau total 150 data. Sedangkan data testing adalah 15 data per kelas atau total 750 data.

\subsection{Ektraksi Ciri}

Ekstraksi ciri ini merupakan salah satu bagian terpenting dan berpengaruh terhadap akurasi hasil pengenalan. Untuk data testing dan data template dilakukan ekstraksi ciri yang sama untuk mendapatkan vektor ciri. Vektor ciri merupakan nilai-nilai hasil pengolahan data-data flex dan data accelerometer yang kemudian diatur sedemikian rupa membentuk baris angka (nilai). Pada ekstraksi ciri ini dilakukan perhitungan mean, nilai simpangan baku, dan kuantisasi seperti pada penelitian [7]. Proses ekstraksi ciri ini akan menghasilkan vektor ciri dengan panjang data yang tidak sama, meskipun pada data file untuk kelas yang sama. Gambar 2 menunjukkan blok diagram proses ekstraksi ciri. 


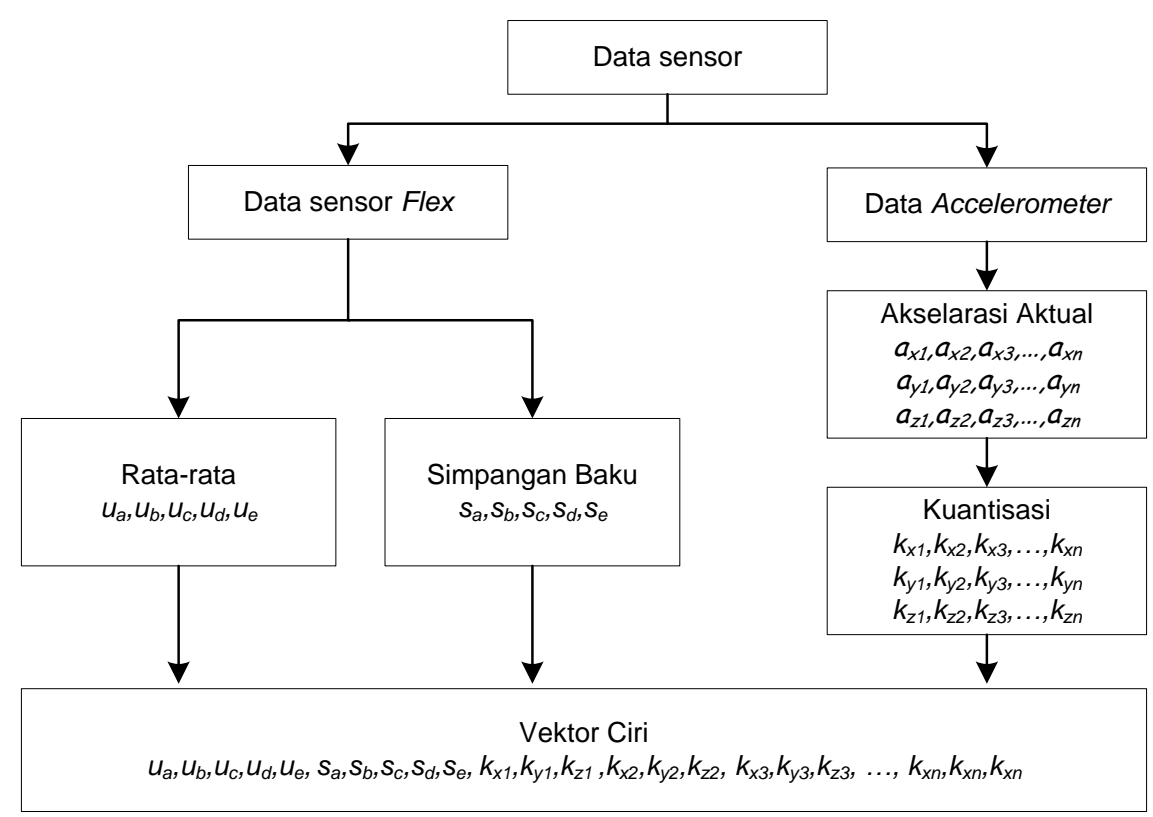

Gambar 2. Diagram Blok Desain Sistem Pengenalan Offline Bahasa Isyarat Indonesia [7]

\subsection{Metode Pencocokan Pola Menggunakan DTW (Dynamic Time Warping)}

Gerak isyarat merupakan data sekuensial. Tiap elemen data sekuensial diukur dan disimpan pada satu periode waktu yang tetap antara elemen satu dengan yang berikutnya. Salah satu metode untuk membandingkan dua data sekunesial dengan panjang yang berbeda adalah dengan algoritma Dynamic Time Warping (DTW).

DTW merupakan algoritma yang digunakan untuk mengukur kemiripan antara dua sekuensial dengan panjang atau jumlah data yang berbeda. DTW mencocokkan dua sekuensial dengan menghitung tranformasi temporal sehingga keduanya dapat diselaraskan (aligned). Penyelarasan (alignment) adalah optimal jika terukur jarak kumulatif terkecil antara dua sampel yang telah diselaraskan.

Jika diasumsikan terdapat dua data sekuensial, $Q$ dan $C$, dengan panjang masing-masing $n$ dan $m$ sebagaimana persamaan 1 dan persamaan 2 ,

$Q=q_{1}, q_{2}, \ldots, q_{i}, \ldots, q_{n}$

$C=c_{1}, c_{2}, \ldots, c_{j}, \ldots, c_{m}$

Maka untuk menyelaraskan (align) kedua sekuensial tersebut mengunakan DTW, dibentuk matriks $m \times n$ dengan elemen matriks $(i, j)$ berupa nilai jarak $d\left(q_{i}, c_{j}\right)$ antara dua titik $q_{i}$ dan, yaitu $d\left(q_{i}, c_{j}\right)=\left(q_{i}-c_{j}\right)^{2}$. Setiap elemen matriks $(i, j)$ berhubungan dengan penyelarasan (alignment) antara titik $q$ i dan $c_{j}$. Warping path $W$ merupakan sekelompok elemen matriks yang berdampingan yang mendefinisikan pemetaan antara $Q$ dan $C$. Elemen ke- $k$ dari $W$ dirumuskan sebagai $w_{k}=(i, j)_{k}$, sehingga didapat persamaan 3 .

$W=w_{1}, w_{2}, \ldots, w_{k}, \ldots, w_{K}$

dengan: $\max (m, n) \leq K<m+n-1$

Sedangkan path didefinisikan sebagai jarak kumulatif $D(i, j)$ yaitu jarak $d\left(q_{i}, c_{j}\right)$ untuk elemen tersebut ditambah dengan minimum dari jarak kumulatif dari elemen bertetanggaan (adjacent), sebagaimana persamaan 4 .

$D(i, j)=d\left(q_{i}, c_{j}\right)+\min \{D(i-1, j-1), D(i-1, j), D(i, j-1)$

Setelah didapatkan warping path yang optimal maka jarak atau warping cost dihitung berdasarkan persamaan 5 .

$\operatorname{DTW}(Q, C)=\min \left\{\sqrt{\sum_{k=1}^{K} w_{k}}\right\}$ 


\subsection{Evaluasi Kinerja Sistem}

Evaluasi kinerja implementasi offline pengenalan pengenalan bahasa isyarata indonesia dengan bantuan confusion matrix, sebagaimana tabel 1 .

Tabel 1. Confusion matrix dua kelas [8]

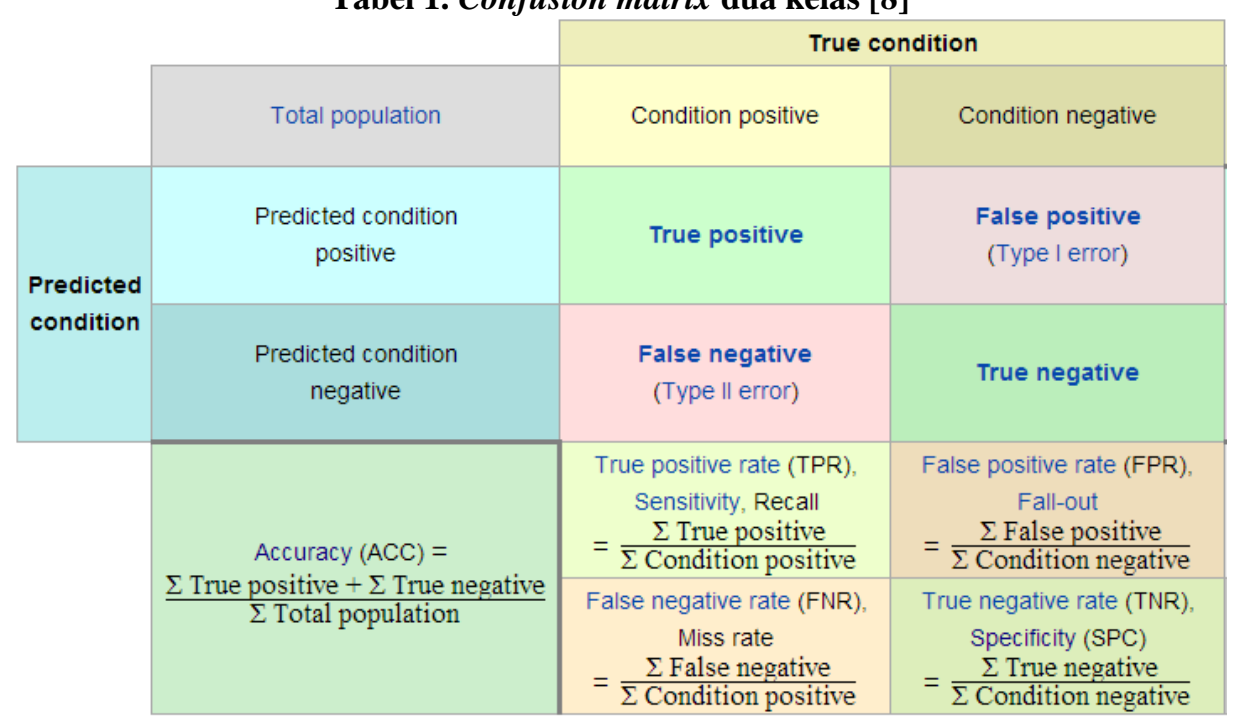

Instrumen pengukuran yang digunakan untuk evaluasi kinerja sistem, yang dihitung dengan berdasarkan data yang tercantun pada confusion matrix adalah accuracy dan sensitivity atau TPR (True Positive Ratio). Accuracy digunakan untuk mengukur kinerja sistem secara keseluruhan sedangkan sensitivty digunakan untuk mengukur kinerja sistem tiap kelas.

Selain evaluasi kinerja sistem menggunakan instrumen pengukuran berdasar confusion matrix, digunakan juga pengukuran berdasarkan waktu yang dibutuhkan untuk tiap proses pengenalan.

\section{HASIL DAN PEMBAHASAN}

Pengembangan aplikasi pada perangkat android menggunakan bahasa pemrograman android dengan bantuan software adt-bundle-windows-x86_64-20131030 yang merupakan integrasi eclipse dengan ADT (Android Development Tool) sebagai tool pengembangan aplikasi berbasis android. Aplikasi android yang dikembangkan diberi nama SIBI Blue.

Tahap pengembangan aplikasi pada penelitian ini adalah pembuatan program untuk implementasi offline pengenalan sistem isyarat bahasa isyarat indonesia. Selain untuk mengetahui kebenaran penerapan metode DTW, juga untuk mengukur atau melakukan evaluasi kinerja sistem. Perangkat android yang digunakan adalah memiliki spesifikasi Processor Dual Core Snapdragon MSM8625 dengan kecepatan akses hingga 1,2 Ghz, dibekali dengan RAM 768 MB dan memori internal 4GB.

Proses pengenalan dilakukan secara offline, artinya menggunakan data yang tersimpan dalam bentuk file. File atau data offline ini didapatkan pada proses akuisisi data untuk penelitian sebelumnya. Metode pencocokan pola yang digunakan adalah metode menghitung jarak antara dua data sekuensial menggunakan DTW. Proses pencocokan pola dilakukan dengan menghitung jarak DTW untuk satu data testing dengan semua data yang ada di template, dari data-data jarak yang diperoleh kemudian dicari jarak yang paling dekat. Jika data template yang mempunyai jarak terdekat dengan data testing, maka data template tersebut akan menjadi data yang paling cocok dengan data testing, sehingga dapat ditentukan kelasnya.

Pada gambar 3 menunjukkan hasil pengenalan kata 'adik'. Pada gambar 3(a), file 001_adik_011.ibi dikenali benar oleh sistem sebagai kata 'adik' yaitu sesuai dengan nilai DTW terkecil $=1,6907903$ terhadap file 001_adik_002.ibi yang dijadikan sebagai salah satu templatenya. Sedangkan gambar 3(b), file 001_adik_015.ibi dikenali benar oleh sistem sebagai kata 'adik' yaitu sesuai dengan nilai DTW terkecil $=2,9 \overline{285197}$ terhadap file 001_adik_002.ibi yang dijadikan sebagai salah satu templatenya. 


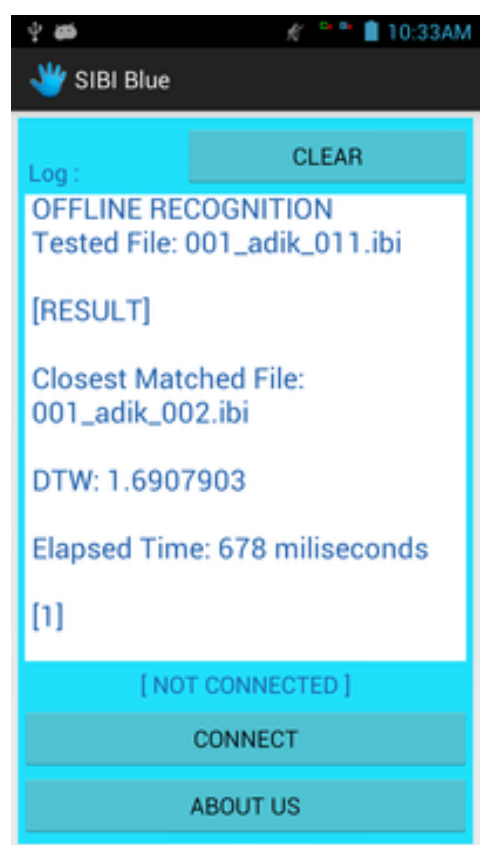

(a)

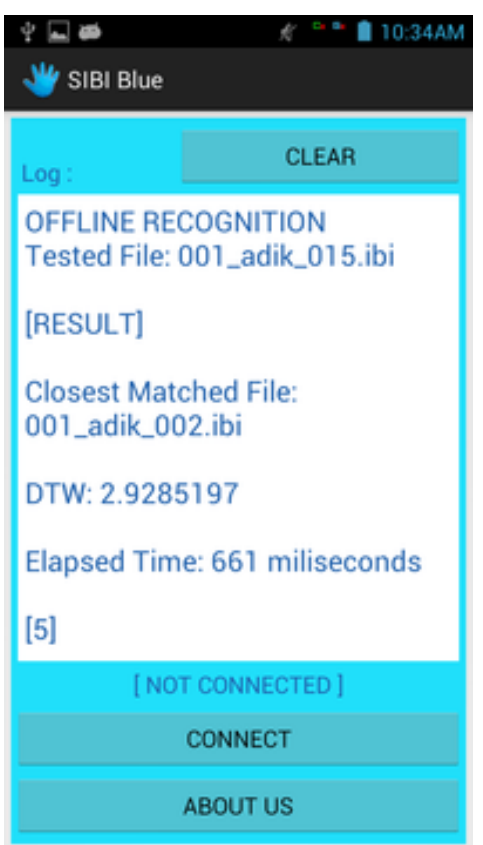

(b)

Gambar 3. Tampilan Pada Pengenalan Kata Isyarat 'adik'

Pada gambar 4 menunjukkan hasil pengenalan kata 'ajak'. Pada gambar 4(a), file 002_ajak_016.ibi dikenali benar oleh sistem sebagai kata 'ajak' yaitu sesuai dengan nilai DTW terkecil $=2,4316094$ terhadap file 002_ajak_003.ibi yang dijadikan sebagai salah satu templatenya. Sedangkan gambar 4(b), file 002_ajak_020.ibi dikenali benar oleh sistem sebagai kata 'ajak' yaitu sesuai dengan nilai DTW terkecil = 2,9661014 terhadap file 002_ajak_003.ibi yang dijadikan sebagai salah satu templatenya.

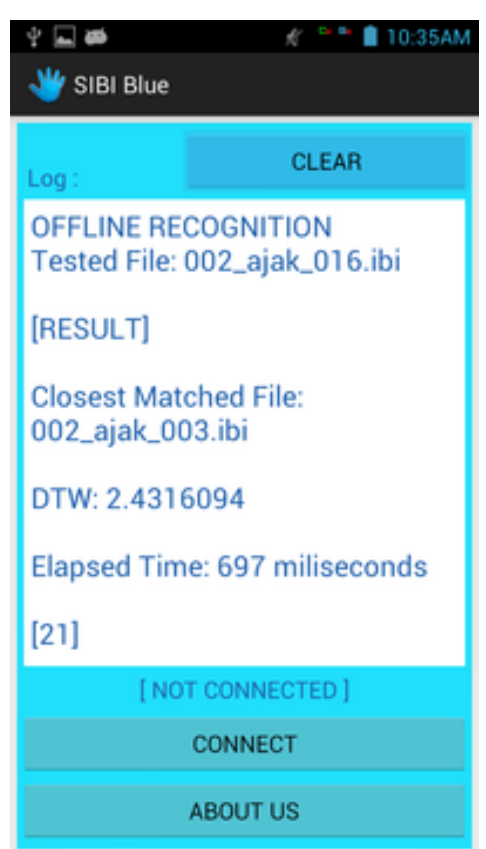

(a)

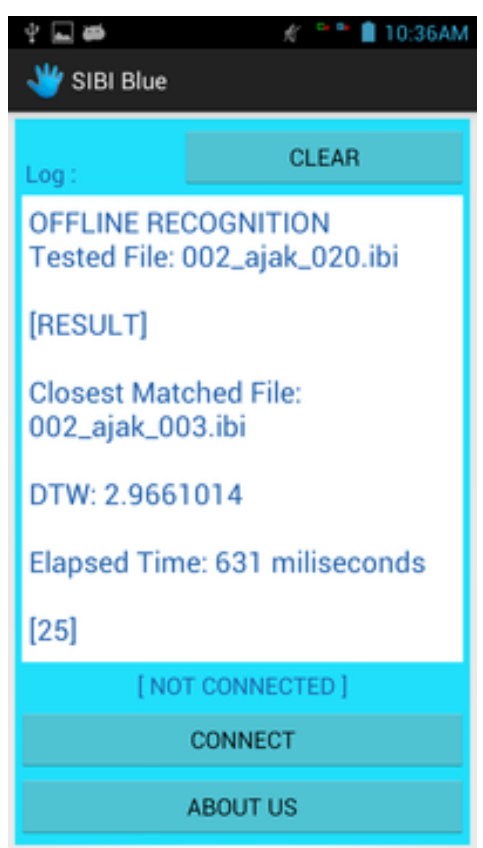

(b)

Gambar 4. Tampilan Pada Pengenalan Kata Isyarat 'ajak

Pada gambar 5 menunjukkan hasil pengenalan kata 'ambil' dan kata 'apel' sebagai contoh hasil pengenalan yang salah oleh sistem. Pada gambar 5(a), file 004_ambil_023.ibi dikenali salah oleh sistem sebagai kata 'adik' yaitu sesuai dengan nilai DTW terkecil $=4,9645243$ terhadap file 001_adik_003.ibi yang dijadikan sebagai salah satu templatenya. Sedangkan gambar 5(b), file 005_apel_011.ibi dikenali salah oleh sistem sebagai kata 'harus' yaitu sesuai dengan nilai DTW terkecil $=3,995636$ terhadap file 014_harus_002.ibi yang dijadikan sebagai salah satu templatenya. 


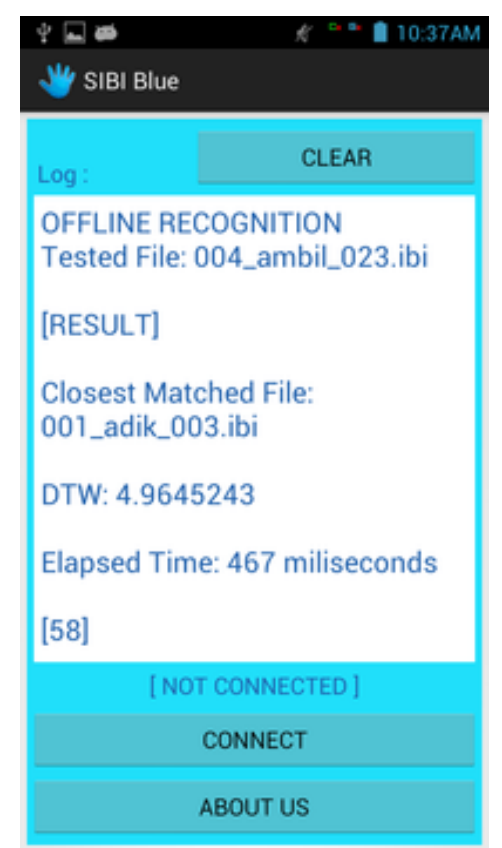

(a)

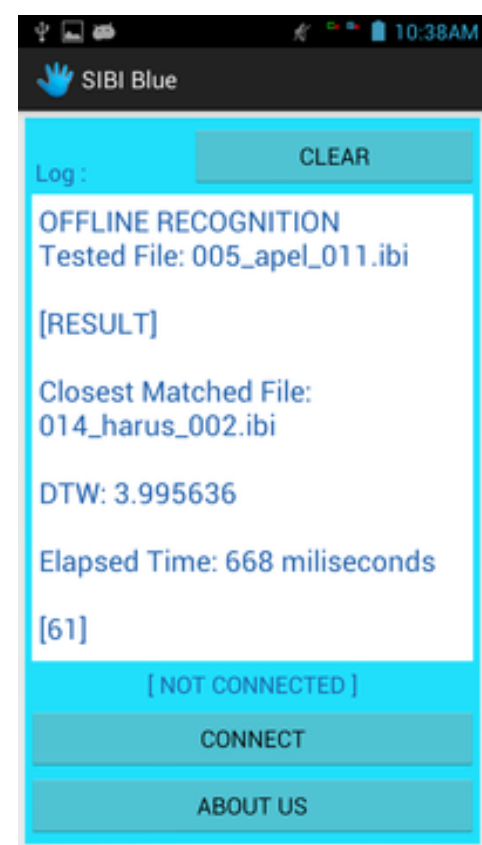

(b)

Gambar 5. Tampilan Pada Pengenalan Kata Isyarat 'ambil' Dan 'apel'

Hasil lengkap untuk pengenalan offline untuk 750 data testing sebagaimana diperlihatkan pada tabel 3. Berdasarkan kelasnya, nampak pada tabel bahwa 25 kata isyarat dapat dikenali sesuai kelasnya, yaitu ditunjukkan dengan nilai sensitivity sebesar $100 \%$. Meskipun demikian terdapat satu kata isyarat dengan nilai sensitivy sebesar 33\% yaitu untuk kata isyarat 'maaf'. Pada data yang lebih detail pada tabel 2 , ternyata kata isyarat 'maaf' lebih banyak dikenali sebagai kata isyarat 'kemarin' dan dua di antaranya dikenali sebagai kata 'sopan'.

Tabel 2. Hasil detail kata isyarat 'maaf'

\begin{tabular}{cccc}
\hline No & Nama file kata isyarat & Dikenalisebagai & DTW \\
\hline 1 & 026_maaf_011.ibi & 026_maaf_002.ibi & 3.037023 \\
2 & 026_maaf_012.ibi & 026_maaf_002.ibi & 2.724542 \\
3 & 026_maaf_013.ibi & 021_kemarin_003.ibi & 2.730529 \\
4 & 026_maaf_014.ibi & 021_kemarin_003.ibi & 2.782734 \\
5 & 026_maaf_015.ibi & 021_kemarin_003.ibi & 2.842935 \\
6 & 026_maaf_016.ibi & 041_sopan_003.ibi & 2.639532 \\
7 & 026_maaf_017.ibi & 026_maaf_001.ibi & 2.184742 \\
8 & 026_maaf_018.ibi & 021_kemarin_001.ibi & 2.437264 \\
9 & 026_maaf_019.ibi & 021_kemarin_003.ibi & 2.452122 \\
10 & 026_maaf_020.ibi & 021_kemarin_001.ibi & 2.731976 \\
11 & 026_maaf_021.ibi & 041_sopan_003.ibi & 2.932506 \\
12 & 026_maaf_022.ibi & 021_kemarin_003.ibi & 2.815367 \\
13 & 026_maaf_023.ibi & 021_kemarin_001.ibi & 2.206296 \\
14 & 026_maaf_024.ibi & 026_maaf_003.ibi & 2.769988 \\
15 & 026_maaf_025.ibi & 026_maaf_001.ibi & 1.483388 \\
\hline
\end{tabular}


Tabel 3. Hasil pengenalan offline pengenalan sistem isyarat bahasa indonesia

\begin{tabular}{|c|c|c|c|c|}
\hline No & Kata Isyarat & True Positive (TP) & Sensitivity & Waktu Rata-rata(ms) \\
\hline 1 & adik & 15 & $100 \%$ & 652 \\
\hline 2 & ajak & 15 & $100 \%$ & 715 \\
\hline 3 & akan & 15 & $100 \%$ & 744 \\
\hline 4 & ambil & 14 & $93 \%$ & 662 \\
\hline 5 & apel & 14 & $93 \%$ & 655 \\
\hline 6 & ayah & 15 & $100 \%$ & 938 \\
\hline 7 & belum & 14 & $93 \%$ & 666 \\
\hline 8 & buah & 13 & $87 \%$ & 806 \\
\hline 9 & cari & 15 & $100 \%$ & 839 \\
\hline 10 & dengar & 15 & $100 \%$ & 662 \\
\hline 11 & dia & 15 & $100 \%$ & 682 \\
\hline 12 & dulu & 15 & $100 \%$ & 712 \\
\hline 13 & gadis & 13 & $87 \%$ & 686 \\
\hline 14 & harus & 13 & $87 \%$ & 640 \\
\hline 15 & haus & 15 & $100 \%$ & 630 \\
\hline 16 & ibu & 11 & $73 \%$ & 663 \\
\hline 17 & ikan & 15 & $100 \%$ & 702 \\
\hline 18 & kakak & 15 & $100 \%$ & 643 \\
\hline 19 & kami & 15 & $100 \%$ & 706 \\
\hline 20 & kamu & 15 & $100 \%$ & 627 \\
\hline 21 & kemarin & 11 & $73 \%$ & 584 \\
\hline 22 & kita & 14 & $93 \%$ & 609 \\
\hline 23 & lihat & 13 & $87 \%$ & 653 \\
\hline 24 & lupa & 14 & $93 \%$ & 751 \\
\hline 25 & lusa & 12 & $80 \%$ & 570 \\
\hline 26 & maaf & 5 & $33 \%$ & 596 \\
\hline 27 & mandi & 14 & $93 \%$ & 618 \\
\hline 28 & masih & 15 & $100 \%$ & 619 \\
\hline 29 & milik & 15 & $100 \%$ & 705 \\
\hline 30 & minta & 15 & $100 \%$ & 581 \\
\hline 31 & minum & 12 & $80 \%$ & 578 \\
\hline 32 & obat & 10 & $67 \%$ & 628 \\
\hline 33 & pakai & 13 & $87 \%$ & 671 \\
\hline 34 & pandai & 13 & $87 \%$ & 682 \\
\hline 35 & saja & 13 & $87 \%$ & 606 \\
\hline 36 & sakit & 15 & $100 \%$ & 631 \\
\hline 37 & saya & 15 & $100 \%$ & 573 \\
\hline 38 & selesai & 13 & $87 \%$ & 582 \\
\hline 39 & senang & 8 & $53 \%$ & 565 \\
\hline 40 & siapa & 15 & $100 \%$ & 663 \\
\hline 41 & sopan & 15 & $100 \%$ & 565 \\
\hline 42 & sudah & 15 & $100 \%$ & 587 \\
\hline 43 & suka & 12 & $80 \%$ & 684 \\
\hline 44 & supaya & 10 & $67 \%$ & 668 \\
\hline 45 & teh & 11 & $73 \%$ & 521 \\
\hline 46 & telepon & 15 & $100 \%$ & 594 \\
\hline 47 & tidak & 15 & $100 \%$ & 621 \\
\hline 48 & topi & 15 & $100 \%$ & 605 \\
\hline 49 & untuk & 15 & $100 \%$ & 691 \\
\hline \multirow[t]{2}{*}{50} & yang & 8 & $53 \%$ & 697 \\
\hline & JUMLAH & 673 & & \\
\hline
\end{tabular}


Berdasarkan tabel 3, maka nilai accuracy atau tingkat pengenalan sistem adalah $(673 * 100 \%$ / 750) $=89,73 \%$. Sedangakan waktu rata-rata yang diperlukan untuk tiap proses pengenalan adalah 654.59 milidetik.

\section{KESIMPULAN}

1) Pengenalan Offline sistem isyarat bahasa indoneisia menggunakan 50 kelas atau jenis kata isyarat kata, dengan jumlah data template sebanyak 3 data, dan jumlah data testing sebanyak 750 data, mendapatkan nilai akurasi sebesar $89,73 \%$.

2) Waktu rata-rata yang dibutuhkan adalah 654.59 milidetik untuk proses pengenalan satu data testing dengan menggunakan template sebanyak 3 data per kelas atau total template 150 data.

\section{UCAPAN TERIMA KASIH}

Penelitian ini didanai oleh DP2M DIKTI (Direktorat Penelitian dan Pengabdian Kepada Masyarakat, Direktorat Jenderal Pendidikan Tinggi) melalui Program Desentralisasi Penelitian Hibah Bersaing Tahun 2015. Penulis mengucapkan terima kasih kepada DIKTI, Kopertis Wilayah VI dan Universitas Muria Kudus.

\section{DAFTAR PUSTAKA}

[1] Reyes,M., Dominguez, G., and Escalera, S. (2011), "Feature weighting in dynamic time warping for gesture recognition in depth data". In Computer Vision Workshops (ICCV Workshops), 2011 IEEE International Conference on, pages $1182-1188$

[2] Ginevra Castellano, Santiago D. Villalba, and Antonio Camurri, (2007), "Recognising Human Emotions from Body Movement and Gesture Dynamics”, ACII 2007, LNCS 4738, pp. 71-82, 2007. Springer-Verlag Berlin Heidelberg 2007

[3] Samsu Sempena, Nur Ulfa Maulidevi, Peb Ruswono Aryan,(2011) "Human Action Recognition Using Dynamic Time Warping”, 2011 International Conference on Electrical Engineering and Informatics 17-19 July 2011, Bandung, Indonesia.

[4] Wen Gao, Gaolin Fang, Debin Zhao, Yiqiang Chen, (2015), "Transition Movement Models for Large Vocabulary Continuous Sign Language Recognition”, DOI: 10.1109/AFGR.2004.1301591Source: IEEE Xplore

[5] Endang S, Mohammad Iqbal, (2013), "Recognition System of Indonesia Sign Language based on Sensor and Artificial Neural Network”, Makara Seri Teknologi, 2013, 17(1): 25-31 DOI: 10.7454/mst.v17i1.1924

[6] Eamonn Keogh (2002). Exact indexing of dynamic time warping. Proceedings of the $28^{\text {th }}$ VLDB Conference, Hong Kong, China

[7] Mohammad Iqbal, Endang Supriyati (2012), "Ekstraksi Ciri pada Pengenalan Sistem Isyarat Bahasa Indonesia Berbasis Sensor Flex dan Accelerometer", Seminar Nasional Embedded System (SNES), 20 Septemer 2012, LIPI, Bandung

[8] https://en.wikipedia.org/wiki/Confusion_matrix 